\title{
FINNISH PRIMARY AND PRESCHOOL TEACHERS REFLECTING ON GENERIC SKILLS: HELSINKI UNIVERSITY GRADUATES’ PERCEPTIONS
}

\author{
Inkeri Maria Ruokonen \\ University of Turku, University of Helsinki, Finland
}

\author{
Anu Sepp \\ University of Helsinki, Finland, Estonian Academy of Music and Theatre, Estonia
}

\begin{abstract}
Lately there has been much interest in how university level studies develop students' generic skills and to what extent university education meets the requirements of working life. Generic skills are needed in every profession and field. The term has been widely used during the past few decades due to the rapid change in society and working life. In order to develop teacher education in Finland, several research projects have been launched.

The aim of this research was to find out preschool and primary school teachers' perceptions to what extent and what kind of generic skills their teacher's pedagogical studies had supported most. The data used in this study was collected electronically by E-lomake that was distributed through different social media channels. The received answers of induction phase teachers $(n=23)$ were analyzed both qualitatively and quantitatively. To gain a better insight, two of the respondents were also interviewed and the answers analysed qualitatively.

The results revealed that in general the respondents found that the attained generic skills helped them to cope with working life. Communication in a foreign language, acting in a multicultural environment, digital and communicative skills, and coping with stress were mentioned as not relevant or needing more attention.
\end{abstract}

Keywords: generic skills, Finnish teacher education, induction phase, teacher's pedagogical studies

\section{Introduction}

The fast development of globalization process and technological advancement have caused worldwide increased human activity by the rapid flow of information. This, in turn, has brought about major social, political and cultural changes. Global economic changes have caused shifts in economic strategies which influence the demands of the job market in general and the adequate education furthered by the state in particular (Green, Lingard, Mundy, \& Verger, 2016; Juergensmeyer \& Anheier, 2012; Tikly, 2001).

The meaning and practice of work are also changing, the boundaries between mental and manual work are fading away and becoming challenging, preparation 
processes and training for work are undergoing changes. The acquisition of knowledge and skills are essential for increasing opportunities to find employment and sustainable maintenances, personal empowerment and socioeconomic development in knowledge economies. This means that young people as well as adults need to adapt to the demands of today's societies, possessing a combination of knowledge, practical and social skills, positive attitudes, the ability to adapt to rapidly changing work environments. This in turn, demands reexamining essential topics connected with educational institutions, learning processes, necessary competencies and skills needed to train for any occupation (Rizvi \& Lingard, 2010; Maclean \& Wilson, 2009).

Higher education institutions have been criticized for not meeting the needs of labour market, their too theoretical teaching and their lack of innovative initiative in considering the real world situation. Key policy documents have been released by the Organisation for Economic Co-operation and Development (OECD) and the World Bank calling for remodelling of education in a rapidly changing economy and offering different visions for educational reforms (Farrell \& Fenwick, 2007).

Thus, to prepare the future generations for these changes - to face competition, stressful daily life, limited resources and other challenges, also university education needs adjustments and transformations as research results show gaps between the developed skills and competences, and the proficiencies needed in working life (Andrews \& Higson, 2008; Teichler, 2007; Tuononen, Parpala, \& Lindblom-Ylänne, 2019).

\section{Theoretical background}

Teaching and teacher profession are always changing and transforming. According to Männikkö and Husu (2019) teachers' interactive decision-making processes are complex. From the first moment of their work life teachers have to find solutions to different kind of educational problems. This is sometimes challenging especially in their induction phase, meaning the beginning of their work career. In real educational situations, teachers usually do not have the time to distance themselves and they have no time reflect analytically upon the variable demands of various educational situations. That is why the pedagogical studies, generic skills studies and later the further educational studies as well as peer mentoring activity are important for supporting teachers in their life-long learning process. In Finland all professional teachers study $60 \mathrm{cp}$ teacher's pedagogical studies. During these studies also the generic skills of teacher's profession are in focus. University students are expected to develop not only pedagogical content knowledge, but also diverse academic competence and skills, such as analytical, communication, teamwork and problem-solving skills, enabling to succeed in 
new situations, manage and adapt to changes (Van Dierendonck \& Van der Gaast, 2013; Tait \& Godfrey, 1999). These are often referred to as „generic skills" - skills that are needed in every field of study and occupation. According to National Centre for Vocational Education Research (NCVER), generic skill is ,a skill which is not specific to work in a particular occupation or industry, but is important for work, education and life generally, including communication skills, mathematical skills, organizational skills, computer literacy, interpersonal competence and analytical skills (NCVER, 2003).

Generic skills are also known by a number of terms like transferable skills, key skills, employability skills, core competences and generic competences as well as generic attributes, depending on the context and country, yet referring to the same kind of competences and skills (Suleman, 2018; Strijbos, Engels, \& Struyven, 2015; Barrie, 2006; Lizzio, Wilson, \& Simons, 2002; Havard, Hughes, \& Clarke, 1998). In some countries they are specifically employment related, while in others greater emphasis has been placed on their social relevance. In this study, the term used is "generic skills“ in the meaning of all the abovementioned

Generic skills have also been included in national and international qualification frameworks such as the European Qualifications Framework (EQF, 2008), which enables a comparison of learners' knowledge, skills and competencies irrespective of where they gained their qualifications (European Qualifications Framework, 2008). Worldwide, numerous business leaders, politicians and educators have developed models and lists of twenty-first century skills that pupils and students need in their lives and work,both today and in the future (e.g. ACT21S 2012; Fadel, Bialik, \& Trilling 2015; Gordon et al., 2009; P21).

Gordon et al. (2009) identify eight key competences, initially the framework for lifelong learning - communication in the mother tongue, communication in foreign languages, mathematical competence, basic competence in science and technology, communication digital competence, learning to learn, social and civic competences, a sense of initiative, entrepreneurship, and cultural awareness and expression-, which are being underpinned by transversal competences such as critical thinking, creativity, initiative, problem solving, risk assessment, decision taking and the constructive management of feelings.

As a result of the Bologna Process the educational systems in all European countries are in the constant process of reforming and developing. In order to connect the rich diversities and develop discussions in the realm of higher education about the comparability of curricula (in terms of structures, programmes and actual teaching), a process called „Tuning educational structures in Europe" started in 2000 (González \& Wagenaar, 2003). First, it was planned as a project to carry out the ideas of Bologna process and at a later stage the Lisbon 
Ruokonen \& Sepp, 2020. Finnish Primary and Preschool Teachers Reflecting on Generic Skills: Helsinki University Graduates’ Perceptions

Strategy in the sector of higher education. Yet, it developed into a cycle of programmes and researches (TUNING 2009; Fallows \& Steven, 2000). According to this source, generic skills and competencies are differentiated and categorised as following:

Table 1 Categorisation of generic skills and competencies (González \& Wagenaar, 2003)

\begin{tabular}{|c|c|}
\hline $\begin{array}{l}\text { Instrumental } \\
\text { competences }\end{array}$ & $\begin{array}{l}\text { cognitive abilities, methodological abilities, technological abilities, } \\
\text { linguistic abilities: capacity for analyses and synthesis, capacity for } \\
\text { organisation and planning, basic general knowledge, grounding in basic } \\
\text { knowledge of the profession, oral and written communication in your } \\
\text { native language, knowledge of a second language, elementary computing } \\
\text { skills, information management skills - ability to retrieve and analyse } \\
\text { information from different sources, problem solving, decision-making. }\end{array}$ \\
\hline $\begin{array}{c}\text { Interpersonal } \\
\text { competences }\end{array}$ & $\begin{array}{l}\text { individual abilities like social skills (social interaction and cooperation): } \\
\text { critical and self-critical abilities, teamwork, interpersonal skills, ability to } \\
\text { work in an interdisciplinary team, ability to communicate with experts in } \\
\text { other fields, appreciation of diversity and multiculturality, ability to work } \\
\text { in an international context, ethical commitment. }\end{array}$ \\
\hline $\begin{array}{c}\text { Systemic } \\
\text { competences }\end{array}$ & $\begin{array}{l}\text { abilities and skills concerning whole systems (combination of } \\
\text { understanding, sensibility and knowledge; prior acquisition of } \\
\text { instrumental and interpersonal competencies required): capacity for } \\
\text { applying knowledge in practice, research skills, capacity to learn, } \\
\text { capacity to adapt to new situations, capacity for generating new ideas } \\
\text { (creativity), leadership, understanding of cultures and customs of other } \\
\text { countries, ability to work autonomously, project design and management, } \\
\text { initiative and entrepreneur spirit, concern for quality, will to succeed. }\end{array}$ \\
\hline
\end{tabular}

The topic has been of considerable interest in the context of university education in various countries and from different perspectives (Chan \& Fong, 2018; Murdock-Eaton \& Whittle, 2012; Keneley \& Jackling, 2011; Badcock et al., 2010; Ballantine \& McCourt Larres, 2007; Crebert, Bates, Bell, Patrick, \& Gragnolini, 2004; Hager, Holland, \& Beckett, 2002).

Fallows and Stevens underline the aspect that higher education should equip students not only with academic knowledge but also with general skills needed for ",a transfer from the world of education into the world of working life“ (Fallows \& Stevens, 2000, 8).

In Finland the topic of generic skills at university level has been researched in numerous studies lately (Koskinen, 2016; Koivunen, 2016; Tynjälä, Virtanen, Klemola, Kostiainen, \& Rasku-Puttonen, 2016). Pahkala (2015) reports on significant problems written communication skills among first year class teacher students. According to Ryky (2018) most of the examined generalist students from Helsinki University, missed competences especially related to communication and interaction. They also reported that challenges in working life 
were mostly related to these skills. Kauppila (2019) emphasizes the importance of both, formal and informal learning environments in the learning of generic skills. Learning of specific generic skills is essential during university studies, even though it is not always easy to recognize learning them.

Tuononen (2019) explored university graduates' employability and transition to working life (University of Helsinki). The study demonstrated that the ability of graduates to recognise the various academic competences, including generic skills that they developed at university and deep-level learning and effort management in studying are important factors with respect to success in working life (Tuononen, 2019).

Virtanen and Tynjälä (2019) argue that ,although generic skills have received widespread attention from both policymakers and educationalists, little is known regarding how students acquire these skills, or how they should best be taught. For example, in the university setting, generic skills have been taught as separate courses (e.g. courses on speech communication, scientific writing, or presentation skills), or have been integrated within subjects (e.g. an information retrieval course as a part of a research seminar)“(Virtanen \& Tynjälä, 2019, 881). They examined what kind of pedagogical practices were behind the learning of particular eight generic skills (resourcefulness, innovativeness, and creativity; ability to operate in new situations; critical thinking skills; problem-solving skills, decision-making skills; ability to solve occupational problems; continuing learning skills; self-assessment skills) in their study. The results indicated that the learning of such skills did not depend on any single method of teaching or particular pedagogical practice. Rather, learning generic skills demanded the use of various teaching methods and different pedagogical practices, especially combining traditional forms of studying (reading, lecturing, working alone) with methods that encourage students to actively process study contents, connect theory with practice, and collaborate with others (Virtanen \& Tynjälä, 2019).

Recently, Tuononen et al. (2019) conducted a research at nine universities in Finland asking university graduates' $(n=911)$ opinion about the development of generic skills during university studies and how these were related to skills needed in working life. The results revealed that all generic skills were scored more important at work than during the studies developed at university. The biggest differences were reported in organising skills and collaboration skills revealing the need of development of those skills during studies.

\section{Methodology}

This research is part of a 2-year project Ope osaa [Teacher can]during 2018 - 2019, which aim was to develop the future learning skills and the 
competence base of teachers during their pedagogical studies in the Master's program at the Faculty of Education, University of Helsinki.

The project was carried out done in collaboration with the Faculty of Education, subject faculties, training and field schools and other universities (Aalto University and University of the Arts). The aim of the project was to develop well-functioning cooperation models of pedagogical studies for teachers. The materials and outcomes of the project are shared on Ope osaa-website and are accessible by any interested parties and/or universities. Lately there has been much interest in how university level studies develop students' generic skills and to what extent university education meets the requirements of working life.

The purpose of the qualitative research was to explore and examine how recent graduates of the faculty of educational studies from University of Helsinki reflect upon teachers pedagogical knowledge, especially the generic skills acquired during their studies. They were asked to give feedback about their studies, especially considering the development of generic skills at the university and how these skills related to their real working life expectations and needs.

In the present study (see Figure 1), in order to find out preschool and primary school teachers' perceptions of generic skills and real working life needs, content analysis (Cohen, Manion, \& Morrison, 2011) was carried out in few phases. For data collection, questionnaires and interviews are often used together (Harris \& Brown, 2010) - qualitative interviews usually enable to penetrate more deeply into the research themes, while questionnaires provide a wider survey (Kendall, 2008).

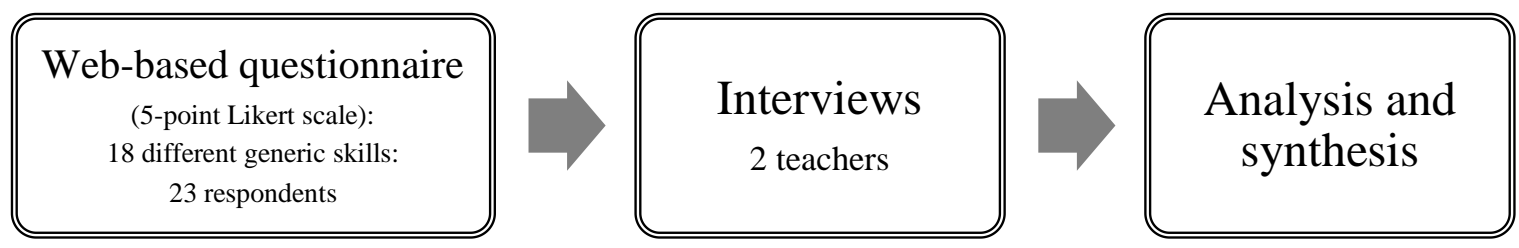

Figure 1 Research design and data

Data were collected by conducting a questionnaire using the E-lomake webbased environment (the first phase of the study). The request to participate in the research was sent via 3 different social media channels (FB groups of pre-school teachers, class teachers, kindergarten teachers) and existing E-mail addresses $(\mathrm{N}=13)$. The questionnaire consisted of closed and open-ended questions (the questionnaire can be reached from: https:/elomake.helsinki.fi/lomakkeet/ 100433/lomake.html.). The closed questions included 18 different generic skills: information and communication technologies (ICT) skills, communicative skills, self-initiative and self-directing, problem-solving skills teamwork skills, the ability to learn and absorb new things, critical thinking skills, negotiation skills, 
design and organizational skills, ability to communicate in a foreign language, collaborative teaching skills creativity, ability to communicate in the mother tongue, pedagogical leadership skills, teaching and training skills, acting in multicultural environment, performing skills, resistance to stress. The respondents had to choose their answer on the 5-point Likert scale. The open-ended questions added some gave the opportunity for the respondents to comment and add some more information about and concerning the generic skills.

Answers were received from 23 university graduates and were analysed both, qualitatively (content analysis) and quantitatively (descriptive statistics).

In order to expand the already collected data, the second phase of the study, 2 interviews were carried out with respondents (R1; R2) who gave their consent. The topics of the semi-structured interviews were derived from the questionnaire. The interview lasted about 45 minutes and were recorded. The data was transcribed and analysed qualitatively by using the content analysis and interpreted by the same categories as in the questionnaire.

Based on the theoretical material, the research instrument for analysing the data was created (table 2). Accordingly, the results are structured basing on those three categories: systemic skills, interpersonal skills and instrumental skills.

Table 2 Research instrument for analysing the generic skills

\begin{tabular}{|l|l|l|}
\hline Instrumental skills & $\begin{array}{l}\text { Interpersonal } \\
\text { skills }\end{array}$ & Systemic skills \\
\hline $\begin{array}{l}\text { information and communication } \\
\text { technologies (ICT) skills }\end{array}$ & $\begin{array}{l}\text { communicative } \\
\text { skills }\end{array}$ & self-initiative and self-directing \\
\hline problem-solving skills & teamwork skills & $\begin{array}{l}\text { the ability to learn and absorb } \\
\text { new information }\end{array}$ \\
\hline critical thinking skills & $\begin{array}{l}\text { negotiation } \\
\text { skills }\end{array}$ & $\begin{array}{l}\text { planning and organizational } \\
\text { skills }\end{array}$ \\
\hline $\begin{array}{l}\text { ability to communicate in a foreign } \\
\text { language }\end{array}$ & $\begin{array}{l}\text { collaborative } \\
\text { teaching skills }\end{array}$ & creativity \\
\hline $\begin{array}{l}\text { ability to communicate in the mother } \\
\text { tongue }\end{array}$ & & pedagogical leadership skills \\
\hline teaching and training skills & & $\begin{array}{l}\text { acting in multicultural } \\
\text { environment }\end{array}$ \\
\hline performing skills & resistance to stress \\
\hline
\end{tabular}

\section{Findings}

The respondents age structure was the following:

under age 25 = 2 respondents; between age 25 - 35 = 16 respondents; over age $35=5$ respondents. 
Out of all the respondents 19 were working as early childhood educators and 4 as class teachers.

Only 9 respondents had previous working experience before their studies in the university and 14 reported to have no working experience in the field.

\section{$I$ - the results of the questionnaire}

The respondents pointed out that the most developed generic skills during their studies had been:

self-initiative and self-directing $(\mathrm{N}=22)$, the ability to learn and absorb new information $(\mathrm{N}=21)$ and critical thinking skills $(\mathrm{N}=16)$.

At the same time the less developed generic skills during their studies appeared to be:

ability to communicate in a foreign language $(N=15)$, ICT skills $(N=13)$, acting in multicultural environment $(N=11)$, problem-solving skills $(N=10)$ and resistance to stress $(\mathrm{N}=10)$.

Some of the respondents added free comments to these answers:

From the standpoint of early childhood educator, there should have been more training in how to survive in the field (Q 9).

Already during the studies there should have been more practice in writing study plans and all the different „papers“ (Q 15).

More time should have been spent on dealing with different documents, writing development plans and also concerning pedagogical leadership (Q 20).

The same list of generic skills was rated for the most needed generic skills concerning their work and all the respondents (all $\mathrm{N}=23$ ) pointed out the following skills:

self-initiative and self-directing, negotiation skills, ability to communicate in the mother tongue and teamwork skills.

Also:

the problem-solving skills, planning and organizational skills and self-initiative and self-directing skills

were rated quite highly (all $\mathrm{N}=22$ ).

The respondents evaluated as the less needed generic skills in their work:

ability to communicate in the mother tongue $(\mathrm{N}=13)$, collaborative teaching skills $(\mathrm{N}=7)$ and acting in multicultural environment $(\mathrm{N}=7)$.

There were some interesting comments on the generic skills needed in working life:

Working in a kindergarten is really very stressful. One has to be very creative and possess good problem solving skills in a somewhat chaotic reality. Very many are leaving the field and feel really burnout. The university is not to blame, but the endless cuttings, changes and.... are the real cause $(Q 3)$.

There is not even 1 minute for yourself to take a breath. There's not enough timethis is the reason why so many are giving up the job (Q 4). 
Proceedings of the International Scientific Conference. Volume II, May $22^{\text {th }}-23^{\text {th }}, 2020.292-304$

The workload is enormous ....more time and more „tools" for pedagogical leadership would be needed (Q 7).

Concerning my work, the should be more contact lessons and practise in arts and craft subjects $(Q 22)$.

\section{II - results of the interviews}

The first interviewee (R1) holds a Master's degree in education but is also a qualified early childhood education teacher. She works as a teacher in a kindergarten. She has been in the field for almost 20 years. Her also had earlier working experiences in arts design.

The second interviewee (R2) holds a Bachelor's degree in education. During the interview she didn't attend lectures any more, but was writing her Master's thesis to graduate in educational sciences. She also had a vocational training as a nurse.

One of the major topics of concern was writing and compiling different documents.

Lately there have been so many changes concerning early childhood education.

And the working load of writing and planning different documents has increased enormously. Teachers definitely need more support like mentoring or in-service courses in compiling and fulfilling all those papers (R1).

I think that the written documents and especially assessment of the child's development needs more clarification, supporting and time. All the endless changes are happening There are so many other things to do..... not enough time left for children (R2).

The first interviewee also pointed out that although early childhood teachers have the pedagogical knowledge, they need more skills how to use it and put it into action.

We should discuss and think more about how teachers can help and support children in their development and growth....... I think that the question about the real role of the teacher and their tasks need more clarifications....... and what duty every member of the staff has in the kindergarten. The teachers are overloaded with work (R1).

Teachers also pointed to the connection between burnout and teamwork skills.

The working load is really heavy. But it also depends greatly on the team you are working with. ... sometimes, when the colleague is constantly away for some reason and there is no replacement available, all the work is on on your shoulders... it is really exhausting and stressful ( $R 2)$.

The tasks should be better .... more exactly distributed between the staff: what are the tasks of the teacher, what are the tasks of the nanny. . I suggest that the whole concept of kindergarten structure needs change...... and different teams within one institution should cooperate more (R1). 
Definitely one of the important skills that came up in different contexts were communicative skills.

I remember that during my studies we discussed a lot in groups and during lectures. I find it very important and that's why there should not be any cutting in this. ..... During my first years at work I remember that it was sometimes difficult to communicate with some parents - how to discuss on some difficult issues or deal with emotions (R1).

As a teacher you need to communicate with different people on different levels like parents, social workers, schools, health services, cultural institutions etc .... also in multicultural surroundings. I find the last could need some more .... skills, knowledge... (R2).

In addition, the interviewees mentioned some really meaningful topics needing mentoring or in-service training like more skills and knowledge concerning first aid (R2), more cooperation regarding arts subjects (R1; R2), multicultural issues (R1, R2), coping with stress (R1), children welfare (R2).

\section{Conclusions and discussion}

The results of this study reveal some interesting information concerning Finnish primary and pre-school teachers' perception about generic skills.

The research revealed that the most developed generic skills concerning the respondents' academic studies - self-initiative and self-directing, and the ability to learn and absorb new information - belong to the category of systemic skills (with the exception to critical thinking skills which is part of instrumental skills). While the generic skills that were pointed out as supporting their working life most - self-initiative and self-directing, negotiation skills and teamwork skills (with the exception to the ability to communicate in the mother tongue which is part of instrumental skills)- belong to the category of interpersonal skills.

Comparing the generic skills acquired during academic studies and supporting their working life, there is one skill in common and this is selfinitiative and self-directing (category of systematic skills).

While the overlapping in the less needed skills in academic studies and working life turned out to be the ability to communicate in a foreign language (category of instrumental skills).

Thus, the problem-solving skill (category of problem solving skills), that was mentioned as one of the most needed in working life, turned out to be less supported during the academic studies.

As the data represents only a limited sample of Finnish primary and preschool teachers, the results cannot be generalized. However, some tendencies concerning generic skills can be observed. 
It can be said on the basis of the analyses that generic skills concerning academic studies and working life have some similarities but this topic needs to be further researched.

Half of the countries in Europe do not provide any support or promotion to the teaching profession during their first years of teaching. Teachers' profession is emphasized as a lifelong learning developmental process (Fransson \& Gustafsson, 2008, 7; Kemmis etc., 2014) - it should be seen as a long-term learning process including the university study phase, the transition to work, mentoring and support during the induction phase, and possibilities for professional development and further education during the career. Generic skills are important future learning skills but also they need to be updated as society changes.

\section{References}

Badcock, P.B.T., Pattison, P.E., \& Harris, K-L. (2010). Developing generic skills through university study: a study of arts, science and engineering in Australia. Higher Education 60(4), 441-458.

Ballantine, J., \& McCourt Larres, P. (2007). Cooperative learning: a pedagogy to improve students' generic skills. Education + Training, 49(2), 126-137.

Chan, C.K.Y., \& Fong, E.T.Y. (2018). Disciplinary differences and implications for the development of generic skills: a study of engineering and business students' perceptions of generic skills. European Journal of Engineering Education, 43(6), 927-949.

Clanchy, J., \& Ballard, B. (1995). Generic Skills in the Context of Higher Education. Higher Education Research \& Development, 14(2), 155-166.

Cohen, L., Manion, L., \& Morrison, K. (2011). Research Methods in Education. London: Routledge.

Crebert, G., Bates, M., Bell, B., Patrick, C-J., \& Gragnolini, V. (2004). Developing generic skills at university, during work placement and in employment: graduates' perceptions. Higher Education Research \& Development, 23(2), 147-165.

EQF. (2008). European Qualifications Framework. Retrieved from http://ec.europa.eu/ education/lifelong-learning-policy/eqf_en.htm

Fallows, S., \& Steven, C. (2000). Integrating key skills in higher education: Employability, transferable skills and learning for life. London: Kogan Page.

Farrell, L., \& Fenwick, T.J. (2007). Educating the Global workforce: Knowledge, Knowledge Work and Knowledge Workers. London: Routledge.

Fransson, G., \& Gustafsson, C. (2008). Newly Qualified teachers in northern Europe: comparative perspectives on promoting professional development. Gävle: Gävle University Press.

González, J., \& Wagenaar, R. (2003). Tuning educational structures in Europe: Final report, phase one. Bilbao: University of Deusto.

Gordon, J., Halasz, G., Krawczyk, M., Leney, T., Michel, A., Pepper, D. Putkiewicz, E. \& Wisniewski, J. (2009). Key Competences in Europe: Opening Doors for Lifelong Learners Across the School Curriculum and Teacher Education. CASE Network Reports No. 87. Warsaw, Poland: CASE, Center for Social and Economic Research. 
Ruokonen \& Sepp, 2020. Finnish Primary and Preschool Teachers Reflecting on Generic Skills: Helsinki University Graduates’ Perceptions

Green, A., Lingard, B., Mundy, K.E., \& Verger, A. (2016). The handbook of global education policy. Chichester, UK; Malden, MA: John Wiley \& Sons, Ltd.

Hager, P., Holland, S., \& Beckett, D. (2002). Enhancing the learning and employability of graduates: the role of generic skills. Business/Higher education round table, 9, 1-16.

Harris, L.R., \& Brown, G.T.L. (2010). Mixing interview and questionnaire methods: Practical problems in aligning data. Practical Assessment, Research, and Evaluation: Vol. 15, Article 1. Retrieved from https://scholarworks.umass.edu/pare/vol15/iss1/1

Juergensmeyer, M., \& Anheier, H.K. (2012). Encyclopedia of Global Studies. Thousand Oaks, Calif: SAGE Publications, Inc.

Kauppila, K. (2019). Työelämätaitojen oppiminen ja niiden oppimista edistävät oppimisympäristöt yliopisto-opintojen aikana. [Learning of generic skills and learning environments that support their learning during university studies.] University of Helsinki.

Kemmis, S., Heikkinen, H.L., Fransson, G., Aspfors, J., \& Edwards-Groves, C. (2014). Mentoring of new teachers as a contested practice: Supervision, support and collaborative self-development. Teaching and teacher education, 43, 154-164.

Kendall, L. (2008). The conduct of qualitative interview: Research questions, methodological issues, and researching online. In J. Coiro, M. Knobel, C. Lankshear \& D. Leu (Eds.), Handbook of research on new literacies (133-149). New York: Lawrence Erlbaum Associates.

Keneley, M., \& Jackling, B. (2011). The acquisition of generic skills of culturally diverse student cohorts. Accounting Education: An International Journal, 20(6), 605-623.

Koivunen, T. (2016). Geneeriset taidot ja oppimisen lähestymistavat maisteriksi valmistuneilla. Helsingin yliopisto. Helsingfors universitet.

Koskinen, H. (2016). Yleisten työelämävalmiuksien kehittyminen yliopisto-opintojen aikana kandidaattien ja maisterien arvioimana ja kuvaamana. University of Helsinki.

Maclean, R., \& Wilson, D. (Eds.). (2009). International Handbook of Education for the Changing World of Work. Bridging Academic and Vocational Learning, vol.1. Bonn, UNEVOC International Centre for Technical and Vocational Education and Training \& Springer.

Murdoch-Eaton, D., \& Whittle, S. (2012). Generic skills in medical education: Developing the tools for successful lifelong learning. Medical Education, 46(1),120-128.

Männikkö, I., \& Husu, J. (2018). Uncovering expected teaching actions in attention-demanding teaching situations. Teacher Development, 22(5), 651-667.

NCVER (National Centre for Vocational Education Research) 2003, Fostering generic skills in VET programs and workplaces: At a glance. NCVER, Adelaide.

Pahkla, M. (2015). Kohti geneerisiä taitoja. Ensimmäisen vuoden luokanopettajaopiskelijoiden kirjallisen osaamistehtävän vastausten analyysi. [Towards generic skills. An analysis of the CLA performance task answers written by first year class teacher students]. University of Helsinki.

Rizvi, F., \& Lingard, B. (2010). Globalizing education policy. London: Routledge.

Ryky, P., Helsingin yliopisto, K. t., University of Helsinki, F. o. E. S. \& Helsingfors universitet, P. f. (2018). Yliopisto-opiskelijoiden geneeristen kompetenssien oppiminen, työelämään siirtyminen ja työelämässä kohdatut haasteet. Helsingin yliopisto.

Tait, H., \& Godfrey, H. (1999). Defining and Assessing Competence in Generic Skills. Quality in Higher Education, 5(3), 245-253.

Tikly, L. (2001). Globalisation and education in the postcolonial world: towards a conceptual framework, Comparative Education, 37, 22, 151-71. 
TUNING. (2019). https://www.unideusto.org/tuningeu/

Tuononen, T. (2019). Employability of university graduates: The role of academic competences, learning and work experience in the successful transition from university to working life. Helsinki: University of Helsinki.

Tuononen, T., Parpala, A., \& Lindblom-Ylänne, S. (2019). Graduates' evaluations of usefulness of university education, and early career success - a longitudinal study of the transition to working life. Assessment \& Evaluation in Higher Education, 44(4), 581-595.

Tynjälä, P., Virtanen, A., Klemola, U., Kostiainen, E., \& Rasku-Puttonen, H. (2016). Developing social competence and other generic skills in teacher education: applying the model of integrative pedagogy. European Journal of Teacher Education, 39(3), 368-387.

Van Dierendonck, D., \& Van der Gaast, E. (2013). Goal Orientation, Academic Competences and Early Career Success. Career Development International, 18(7), 694-711.

Virtanen, A., \& Tynjälä, P. (2019). Factors explaining the learning of generic skills: A study of university students' experiences. Teaching in Higher Education, 24(7), 880 - 894. 